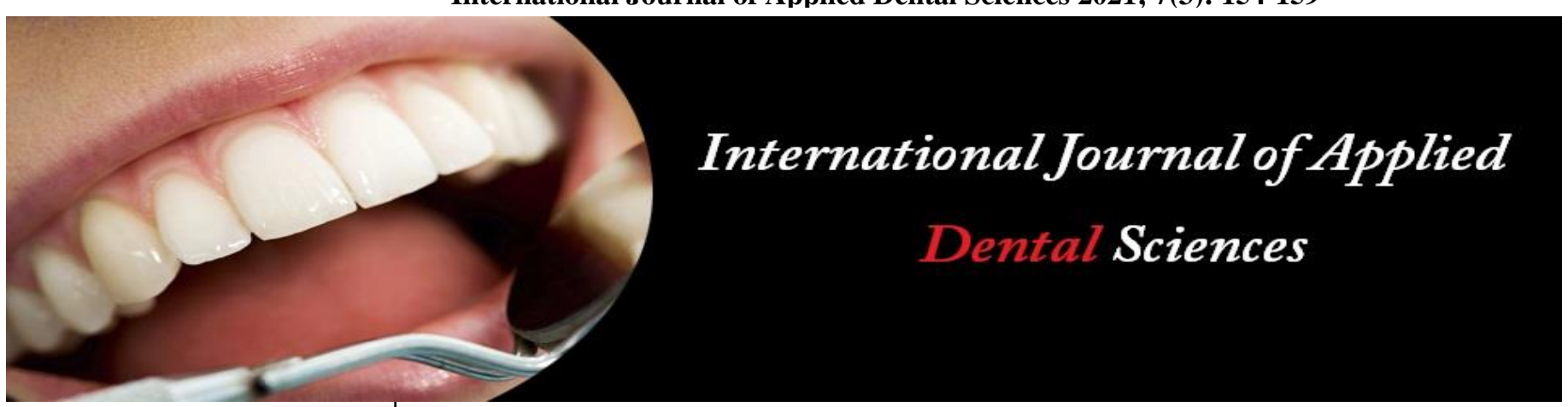

ISSN Print: 2394-7489

ISSN Online: 2394-7497

IJADS 2021; 7(3): 154-159

(C) 2021 IJADS

www.oraljournal.com

Received: 07-05-2021

Accepted: 09-06-2021

Dr. Hiba Shahzad

JR-2, MDS Orthodontics,

Subharti Dental College \&

Hospital, Swami Vivekanand

Subharti University, Meerut,

Uttar Pradesh, India

Dr. Pradeep Raghav

MDS Orthodontics, Professor \&

Head of Department of

Orthodontics and Dentofacial

Orthopedics, Subharti Dental

College \& Hospital, Swami

Vivekanand Subharti

University, Meerut,

Uttar Pradesh, India

Dr. Munish Reddy

MDS Orthodontics, Professor in

Department of Orthodontics and

Dentofacial Orthopedics,

Subharti Dental College \&

Hospital, Swami Vivekanand

Subharti University, Meerut,

Uttar Pradesh, India
Corresponding Author: Dr. Hiba Shahzad

JR-2, MDS Orthodontics, Subharti Dental College \&

Hospital, Swami Vivekanand Subharti University, Meerut,

Uttar Pradesh, India

\section{Esthetic consideration of canine substitution in congenital lateral incisor agenesis}

\author{
Dr. Hiba Shahzad, Dr. Pradeep Raghav and Dr. Munish Reddy
}

DOI: $\underline{\text { https://doi.org/10.22271/oral.2021.v7.i3c.1293 }}$

\section{Abstract}

Introduction: Amongst the anomalies observed in human dentition, agenesis is one of the most commonly found. Maxillary lateral incisor agenesis is one such anomaly. Various treatment modalities involving orthodontic \& prosthetic treatment have been advocated for the management of this anomaly. Objective: To analyze the best treatment modality for maxillary lateral incisor agenesis amongst the orthodontic space closure, prosthetic replacement \& implant based upon the esthetic results.

Methodology: Till October 2020 a thorough literature search in various popular data bases performed with the end result of inclusion of 11 articles.

Result and Conclusion: Esthetic outcomes of all these modalities was found to be satisfactory for patients as well as for the dentists, however orthodontic space closure was considered to be the most appropriate modality for lateral incisor agenesis pertaining to esthetics.

Keywords: lateral incisor agenesis, esthetics, canine substitution, implant, prosthesis, orthodontic space closure

\section{Introduction}

One of the most common developmental dental anomaly is tooth agenesis. Absence of 1 to 6 teeth excluding the third molars is described as hypodontia whereas absence of more than 6 teeth excluding the third molars is described as oligodontia. Anodontia is referred to the condition in which no teeth is present. Genetics / hereditary are the usual cause of congenital absence of teeth. A complex \& poorly defined genetic background is associated with it involving $>200$ genes in formation of a tooth ${ }^{[1,2,3]}$. PAX9 promoter of polymorphisms and hypodontia are associated to each other ${ }^{[4]} \&$ a single nucleotide polymorphisms in the PAX9 gene is associated with a high risk of maxillary lateral incisor agenesis ${ }^{[5]}$. Environmental factors such as trauma, radiotherapy, chemical substances, or drugs \& disturbances in jaw innervations can also account for missing teeth.

Tooth agenesis is more frequently seen in permanent dentition as compared to primary dentition. If only a few teeth are missing, the absent tooth would be the most distal tooth of any given type $[6,7,8]$. This applies to the maxillary laterals and the mandibular second premolars. Unilateral agenesis is more common in the case of the upper and lower second premolars, whereas, bilateral missing is more common in the maxillary laterals ${ }^{[9]}$. While the maxilla is affected by symmetrical dental missing, the mandible shows mostly unilateral agenesis ${ }^{[10]}$.

Esthetic \& treatment planning problems because of age, location, space limitation, alveolar ridge deficiencies, uneven gingival margins, occlusion \& periodontal factors are often encountered by clinicians while managing congenitally missing maxillary lateral incisors. Treatment for a missing maxillary lateral incisor can involve orthodontic space closure i.e. substituting missing lateral incisor with maxillary canine or by replacing it with a prosthesis or implant.

Before deciding the best treatment alternative certain clinical characteristics should be evaluated which include age of the patient, malocclusion type (intermaxillary \& intramaxillary relationships), soft tissue characteristics such as facial profile \& esthetics along with the size and morphology of teeth ${ }^{[11,12,13]}$. 
Other factors governing the treatment planning include specialist education, finances, \& most importantly patients preference. An appropriate selection of patient clinical reports has shown satisfactory result by both space closing \& space maintaining procedures ${ }^{[14]}$.

Authors advocated prosthetic replacement of missing incisor due to long term \& healthy occlusion achieved by canine guidance ${ }^{[15]}$ as well as problem encountered in achieving adequate esthetics by canine substitution for lateral incisor. However, canine substitution is favored by some due to better periodontal conditions observed in it as compared to fixed or removable prosthesis $[16,17]$ furthermore appropriately performed enameloplasty \& adequate lingual root torque given in canine can give natural looking esthetic outcomes ${ }^{[18,}$ $19,20]$.

Systematic review conducted by Andrade et al. ${ }^{[21]}$ in 2011, found no scientific evidence to support any treatment option for maxillary lateral incisor agenesis as no randomized clinical trial (RCT) or quasi RCT was identified. Due to distinct variables involved, the complexity of this clinical problem was high $\&$ if only evidences from rcts are included then no best treatment could be identified. Hence, according to the study conducted by Papageorgiou et al. ${ }^{[22]}$, if RCTs were not possible or inappropriate then based on scientific evidences \& sound reasoning over well conducted prospective non-RCTs, the clinical decision could be made.

Silveira et al. ${ }^{[23]}$ conducted a systematic review in 2016 to determine the best treatment alternative for maxillary lateral incisor agenesis based on periodontal, esthetic \& occlusal outcomes. However, this review included limited study design $\&$ only comparative studies.

Therefore, the aim of this systematic review was to analyze the best treatment modality for maxillary lateral incisor agenesis based upon the esthetic results obtained by orthodontic space closure, prosthetic replacement \& implant.

\section{Search strategy and selection criteria}

This systematic review was conducted to analyze the treatment modalities for maxillary lateral incisor agenesis based on their esthetic outcomes. Literature search conducted thoroughly in Pubmed, Web of science \& Scopus database. MESH terms used for the search were ("upper lateral incisor" OR "maxillary lateral incisor "teeth agenesis" [tiab] OR "tooth agenesis" [tiab] OR hypodontia [tiab] OR oligodontia [tiab] OR “dental agenesis"[tiab] OR “congenitally missing” [tiab] OR "congenitally absent"[tiab] OR "orthodontic movement"[tiab] OR "teeth movement" [tiab] OR Orthodontic space closure[MH] OR "orthodontic space closure" [tiab] OR "orthodontic dental space closure" [tiab] OR "canine substitution" [tiab] OR "mesial movement of canine"[tiab] OR "mesial movement of cuspid" [tiab] OR Dental implants[MH] OR "dental implant"[tiab] OR "single tooth "[tiab] OR "single-tooth implant" [tiab] OR "singletooth implants"[tiab] OR "single-tooth dental implant"[tiab] OR Denture, partial, fixed[MH] OR "Denture partial fixed" [tiab] OR fixed bridge* OR "fixed partial denture"[tiab] OR pontic [tiab] OR Denture, partial, removable[MH] OR "denture removable partial" [tiab] OR Denture, partial, fixed, resin-bonded [mh] OR "maryland bridge dental"[tiab] OR "resin-bonded bridge"[tiab] OR "resin-bonded fixed partial denture"[tiab] OR "resin bonded acid etched fixed partial denture"[tiab] OR Dental prosthesis [MH] OR "dental prosthesis"[tiab] OR "prosthetic replacement" [tiab] OR Dental prosthesis, implant supported $[\mathrm{MH}]$ OR "prosthesis implant-supported dental" [tiab]).

Using PICO criteria (participants, intervention, comparator \& outcome), data extraction was done.

\section{Study design}

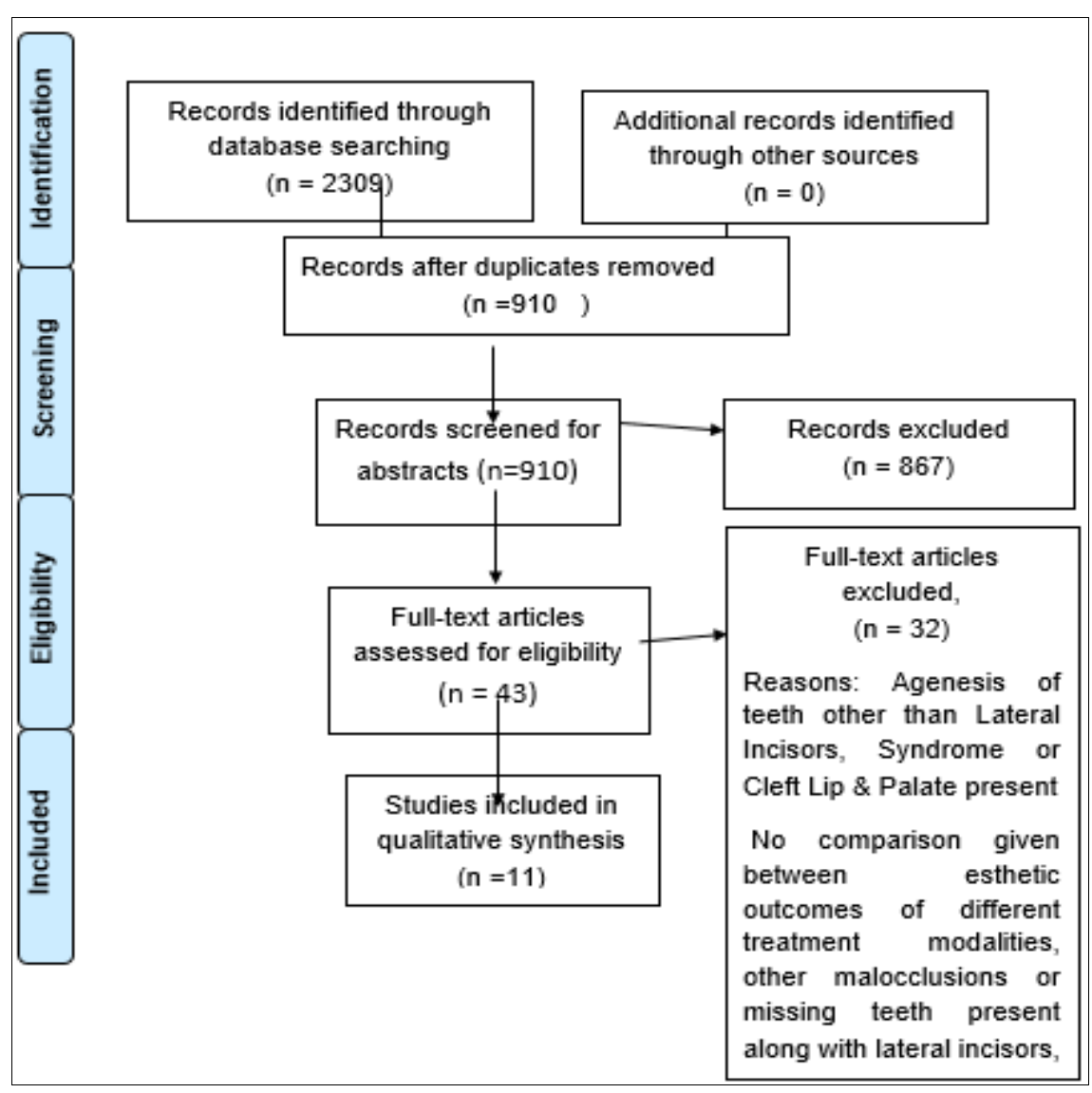

Fig 1: The search algorithm followed according to PRISMA statement $\sim 155 \sim$ 
Table 1: Characteristics of included articles

\begin{tabular}{|c|c|c|c|c|c|}
\hline Author & Study design & Objective & $\begin{array}{c}\text { Method of } \\
\text { measurement }\end{array}$ & Result and Inference & \begin{tabular}{|l}
$\begin{array}{l}\text { Level of } \\
\text { evidence }\end{array}$ \\
\end{tabular} \\
\hline $\begin{array}{c}\text { Robertsson } \\
\text { and Mohlin, } \\
2000^{[17]}\end{array}$ & $\begin{array}{l}\text { Retrospective Study } 50 \text { patients (M- 14; F- } \\
\text { 36) Mean Age } 25.8 \text { y-: } 30 \text { OSC, 20 FPD } 39 \\
\text { patients (bilateral) } 11 \text { patients (unilateral) t } \\
\text { test chi-square (P } 50.05 \text { ) }\end{array}$ & $\begin{array}{l}\text { To } \\
\text { compare } \\
\text { OSC and } \\
\text { FPD }\end{array}$ & $\begin{array}{c}\text { Clinical } \\
\text { examination and } \\
\text { Eastman Esthetic } \\
\text { Index } \\
\text { questionnaire } \\
\end{array}$ & $\begin{array}{c}\text { (OSC>FPD) } \\
\text { Orthodontics Space Closure results are } \\
\text { esthtically well accepted by patients in } \\
\text { comparison with prosthetic replacements }\end{array}$ & Level 3 \\
\hline $\begin{array}{l}\text { Armbruster } \\
\text { et al., } 2005 \\
{[25]}\end{array}$ & \begin{tabular}{|} 
Case control 12 subjects (age \& sex not \\
reported): $3 \mathrm{MB}, 3 \mathrm{DI}, 3$ OSC, $3 \mathrm{ND}$ \\
Evaluators: 43 orthodontists, 140 general \\
dentists, 29 specialists, 40 laypersons 6 \\
patients (bilateral) 3 patients (unilateral) $2-$ \\
way ANOVA 1 -way ANOVA $(\mathrm{P}=0.05)$ \\
\end{tabular} & $\begin{array}{l}\text { To } \\
\text { compare } \\
\text { OSC, DI, } \\
\text { MB, and } \\
\text { ND }\end{array}$ & $\begin{array}{l}\text { Intraoral } \\
\text { photos }\end{array}$ & $\begin{array}{c}\text { Laypersons }(\mathrm{OSC}>\mathrm{ND}>\mathrm{MB}>\mathrm{DI}) \text { General } \\
\text { dentists }(\mathrm{ND}>\mathrm{OSC}>\mathrm{MB}>\mathrm{DI}) \text { Orthodontic } \\
\text { Space Closure results well accepted by all } \\
\text { groups of evaluators than Maryland } \\
\text { Bridges \& Dental Implants }\end{array}$ & Level 4 \\
\hline $\begin{array}{c}\text { Thams et al. } \\
2009^{[27]}\end{array}$ & \begin{tabular}{|c|} 
Case control 12subjects (age \& sex not \\
reported): $2 \mathrm{MB}, 3 \mathrm{DI}, 4$ OSC, $3 \mathrm{NT}$ \\
Evaluators: 15 orthodontists, 15 general \\
dentists, 15 laypersons Not reported \\
(bilateral and unilateral) ANOVA (P = \\
$0.05)$ \\
\end{tabular} & $\begin{array}{l}\text { To } \\
\text { compare } \\
\text { OSC, DI, } \\
\text { MB, and } \\
\text { ND }\end{array}$ & $\begin{array}{l}\text { Intraoral } \\
\text { photos }\end{array}$ & \begin{tabular}{|c|} 
All groups of evaluators \\
(OSC $>$ DI $>$ MB $>$ NT) Orthodontic Space \\
Closure results well accepted by all \\
groups of evaluators than Dental Implants, \\
Maryland Bridges \& lastly non-treated LI \\
agenesis
\end{tabular} & Level 4 \\
\hline $\begin{array}{l}\text { Pini et al., } \\
2012^{[30]}\end{array}$ & $\begin{array}{c}\text { Case control 48patients (M- 9; F-39): } 28 \\
\text { OSC (mean age-24.9y), 20 DI (mean age- } \\
25.1 \mathrm{y}) 25 \mathrm{ND} \text { (mean age-21.3y) } 28 \text { patients } \\
\text { (bilateral) } 20 \text { patients (unilateral) Shapiro- } \\
\text { Wilk Wilcoxon Kruskal-Wallis Mann- } \\
\text { Whitney U post hoc Friedman Post hoc } \\
\text { Wilcoxon }(\mathrm{P}=0.05)\end{array}$ & $\begin{array}{l}\text { To } \\
\text { compare } \\
\text { OSC, DI, } \\
\text { and ND }\end{array}$ & Dental cast & $\begin{array}{l}\text { WHR: LI (mean) (DI=ND=OSC) Width- } \\
\text { Height Ratio For orthodontic space } \\
\text { closure is similar esthetically to Dental } \\
\text { Implants \& normal Dentition }\end{array}$ & Level 4 \\
\hline $\begin{array}{l}\text { Pini et al., } \\
2012^{[31]}\end{array}$ & $\begin{array}{c}\text { Case control } 52 \text { subjects (sex not reported): } \\
18 \text { OSC (mean age-32.4 y), } 10 \mathrm{DI}(\text { mean } \\
\text { age-32.7 y), } 24 \mathrm{ND}(\text { mean age-21.3 y) } 28 \\
\text { patients (bilateral) Shapiro-Wilk Wilcoxon } \\
\text { Kruskal-Wallis t test ANOVA (P = 0.05) }\end{array}$ & $\begin{array}{l}\text { To } \\
\text { compare } \\
\text { OSC, DI, } \\
\text { and ND }\end{array}$ & Dental cast & $\begin{array}{l}\text { WHR: CI, LI, C (OSC=DI=ND) GZ: LI } \\
\text { (OSC=DI=ND) Width_height Ratio \& } \\
\text { Gingival zenith in Orthodontic space } \\
\text { closure, Dental Implants \& Normal } \\
\text { Dentition are esthetically similar }\end{array}$ & Level 4 \\
\hline $\begin{array}{l}\text { Pini et al., } \\
2013^{[32]}\end{array}$ & $\begin{array}{c}\text { Case control } 52 \text { subjects (sex not reported): } \\
18 \text { OSC, } 10 \text { DI, } 24 \text { ND OSC: } 32.4 y \text { DI: } \\
32.7 \text { y ND: } 21.3 \text { y } 28 \text { patients (bilateral) } \\
\text { Shapiro-Wilk Spearman correlation } \\
\text { Kruskal-Wallis }(\mathrm{P}=0.05)\end{array}$ & $\begin{array}{l}\text { To } \\
\text { compare } \\
\text { OSC,DI, } \\
\text { and ND }\end{array}$ & $\begin{array}{l}\text { 3D digital image } \\
\text { from dental } \\
\text { cast }\end{array}$ & $\begin{array}{l}\text { WHR: CI, LI, C (OSC=DI=ND) GZ: LI } \\
\text { (OSC<ND=DI) ACD: (DI>OSC=ND) } \\
\text { Width Height Ratio for central Incisor, } \\
\text { lateral incisor \& canine is similar } \\
\text { esthetically in OSC, DI \& ND whereas } \\
\text { gingival zenith results are inferior in } \\
\text { Orthodontic space closure than DI } \\
\text { Apparent contact dimension is more in } \\
\text { Dental Implant group than Orthodontic } \\
\text { space closure group. }\end{array}$ & Level 4 \\
\hline $\begin{array}{l}\text { De-Marchi } \\
\quad \text { et al., } \\
2014 \text { [33] }\end{array}$ & \begin{tabular}{|c|} 
Case control 68 subjects (M, 52; F, 16): 26 \\
OSC (mean age- 24.9 y) 20 DI (mean age- \\
25.1 y), 22 ND (mean age-21.3y) \\
Evaluators: 20 dentists, 20 laypersons, 68 \\
patients (self-evaluation) 27 patients \\
(bilateral) 19 patients(unilateral) Fischer \\
post hoc Mann-Whitney Shapiro-Wilk t \\
test Cronbach a ICC Kolmogorov Smirnov \\
Multifactorial ANOVA 1-way ANOVA \\
Bonferroni correction (P=0.05) \\
\end{tabular} & $\begin{array}{l}\text { To } \\
\text { compare } \\
\text { OSC, DI, } \\
\text { and ND }\end{array}$ & $\begin{array}{l}\text { Photo of smile-- } \\
\text { lower third of } \\
\text { the face (visual } \\
\text { analog scales) }\end{array}$ & $\begin{array}{c}\text { Laypersons and dentists }(\mathrm{OSC}=\mathrm{DI}=\mathrm{ND}) \\
\text { Self-evaluation }(\mathrm{OSC}=\mathrm{DI}>\mathrm{ND}) \\
\text { (OSC }>\text { ND) Esthetic results for OSC \& } \\
\text { Dental Implants comparable to those with } \\
\text { normal dentition according to laypersons } \\
\text { \& dentists whereas patients on self- } \\
\text { evaluation were more satisfied with OSC } \\
\& \text { DI than normal Dentition }\end{array}$ & Level 4 \\
\hline $\begin{array}{l}\text { Qadri,Parkin } \\
\text { and Benson, } \\
2016^{[29]}\end{array}$ & \begin{tabular}{|c|} 
Cross sectional study, web-based survey. \\
21 subjects (age \& sex not reported) 11 \\
OSC 10 PR Panel- 5 Orthodontists 5 \\
Restorative Dentists Evaluators- \\
Laypersons (9590 Judgements) Two sided \\
paired t test, Logistic regression $(\mathrm{P}=0.05)$
\end{tabular} & $\begin{array}{l}\text { To } \\
\text { compare } \\
\text { OSC and } \\
\text { PR }\end{array}$ & $\begin{array}{l}\text { post-treatment } \\
\text { intra-oral images }\end{array}$ & $\begin{array}{l}\text { Laypeople (OSC }>\text { PR) Laypersons more } \\
\text { satisfied esthetically with OSC than PR }\end{array}$ & Level 3 \\
\hline $\begin{array}{l}\text { Schneider } \\
\text { et al., } 2016 \\
{[28]}\end{array}$ & $\begin{array}{c}\text { Case control } 9 \text { subjects (sex \& age not } \\
\text { reported); } 3 \text { OSC, } 3 \text { DI,3 ND Evaluators: } \\
87 \text { orthodontists, } 100 \text { general dentists, and } \\
100 \text { laypersons Not reported (bilateral and } \\
\text { unilateral) D'Agostino-Pearson test Levene } \\
\text { test, Two way ANOVA }(\mathrm{P}=0.05) \\
\end{array}$ & \begin{tabular}{|l} 
To \\
compare \\
OSC, DI, \\
and ND
\end{tabular} & $\begin{array}{l}\text { Intraoral frontal } \\
\text { photographs }\end{array}$ & $\begin{array}{c}\text { Orthodontist \& Dentist (ND> OSC, DI) } \\
\text { Laypersons (OSC,DI>ND) Orthodontists } \\
\text { \& Dentists preferred normal dentition in } \\
\text { comparison to orthodontic space closure } \\
\text { \& Dental implants whereas opposite was } \\
\text { preferred by layperson }\end{array}$ & Level 4 \\
\hline $\begin{array}{l}\text { Josefsson and } \\
\text { Lindsten, } \\
2018^{[24]}\end{array}$ & $\begin{array}{c}\text { Retrospective study } 44 \text { subjects } 28 \text { DI } \\
(<26 y \text { age } \& \text { M- } 8 \text { F-14), } 34 \text { OSC } 26 \\
\text { unilateral and } 18 \text { bilateral Pearson's chi } \\
\text { square test and Fisher's exact test ( } \mathrm{P}=0.05)\end{array}$ & $\begin{array}{l}\text { To } \\
\text { compare } \\
\text { OSC and } \\
\text { DI }\end{array}$ & $\begin{array}{l}\text { Interview and } \\
\text { clinical } \\
\text { examination }\end{array}$ & \begin{tabular}{|} 
Gingiva color \& crown length $(\mathrm{DI}<\mathrm{OSC})$ \\
Crown Color $(\mathrm{DI}>\mathrm{OSC})$ Pt. and examiner \\
Satisfaction (DI=OSC) Gingiva color \& \\
crown length was better in case OSC in \\
comparison to DI whereas crown color of \\
Dental Implant was more acceptable. \\
However Patient \& examiner satisfaction
\end{tabular} & Level 3 \\
\hline
\end{tabular}




\begin{tabular}{|c|c|c|c|c|c|}
\hline & & & & was similar for both Implants \& OSC. & \\
\hline $\begin{array}{c}\text { Rahimi et al., } \\
2018^{[34]}\end{array}$ & $\begin{array}{l}\text { Cross Sectional Study } 24 \text { Subjects (F-16 } \\
\text { and M-8) mean age of } 26.08 \pm 2.8413 \text { DI, } \\
11 \text { OSC Unilateral Fisher exact test }\end{array}$ & $\begin{array}{l}\text { To } \\
\text { compare } \\
\text { OSC and } \\
\quad \text { DI }\end{array}$ & $\begin{array}{c}\text { Intra oral } \\
\text { Photographs } \\
\text { (frontal view) } \\
\text { evaluated for } \\
\text { White esthetic } \\
\text { score. VAS }\end{array}$ & $\begin{array}{c}\text { Esthetic outcome \& pt satisfaction } \\
\text { (OSC }=\text { DI) } \\
\text { OSC \& DI have comparable esthtic results } \\
\& \text { patients satisfaction }\end{array}$ & Level 3 \\
\hline
\end{tabular}

Table 2: Results of reviewed articles

\begin{tabular}{|c|c|c|}
\hline S. No. & Variables & Significant results \\
\hline 1. & Overall esthetics & Orthodontic space closure esthetically better than prosthetic replacement \& implant ${ }^{[17,26,27,28]}$. \\
\hline 2. & Width-height ratio & Orthodontic space closure, implants \& normal dentition esthetically comparable ${ }^{[30,31,32]}$ \\
\hline 3. & Gingival zenith \& apparent contact dimension & Dental implant more acceptable than orthodontic space closure ${ }^{[32]}$. \\
\hline 4. & Gingiva color \& crown length & Orthodontic space closure more acceptable than implants ${ }^{[24]}$. \\
\hline 5. & Crown color & Dental implant more acceptable than orthodontic space closure ${ }^{[24]}$. \\
\hline 6. & Patient Satisfaction & $\begin{array}{c}\text { Orthodontic space closure equally satisfactory as dental implants }{ }^{[24,34]} \\
\text { Orthodontic space closure more satisfactory to prosthetic replacement }{ }^{[29]} .\end{array}$ \\
\hline
\end{tabular}

\section{Result}

Study selection and characteristics 2309 articles were identified in the initial search, out of them 1399 were excluded to eliminate duplicacy. The titles and abstracts of the 910 remaining articles were accessed, and 867 were excluded because of irrelevance to the subject or inability to fulfill the eligibility criteria. Full reading of text done of 43 articles, and 32 were excluded for the following reasons: absence of teeth in the maxilla other than lateral incisors, syndrome or cleft lip/palate presence, orthodontic treatment with removable appliances, or no comparison of esthetic outcomes of different treatment modalities. The 11 articles that met the inclusion criteria were included in this review which comprised of all type of study designs that compared the esthetic outcomes of different types of treatment (Fig.1). A summary of key methodological data and study results is mentioned in Table 1. Amongst the 11 included studies, two compared the periodontal and occlusal results in patients with space closure with tooth-supported and implant-supported dental prostheses along with esthetic evaluation ${ }^{[17,24]}$.

While the other 9 studies compared only the esthetic results of the different types of treatment. In 5 studies, dental professionals and laypersons evaluated photographs without knowing the type of treatment performed [25, 26, 27, 28, 29]. In 4 studies, different esthetic criteria were used, such as width-toheight ratio, gingival zenith of the maxillary lateral incisor, golden proportion in the 6 anterior teeth, and apparent contact dimension in the same sample, varying only between subjects with unilateral or bilateral agenesis [24, 30, 31, 32]. Patient satisfaction was also considered in 3 studies ${ }^{[24,33,34]}$.

A questionnaire was used by Robertsson and Mohlin [17], in which the opinions of the patients were assessed regarding shape, color, and symmetry of the teeth and the distribution of spaces between them in the anterior region of the maxilla. $93 \%$ subjects were satisfied moderately with orthodontic space closure as compared to $65 \%$ in prosthetic replacement group. The results showed no significant differences between the groups, except for the color of teeth. $80 \%$ of the patients in the prosthetic replacement group were satisfied with the color compared to $40 \%$ in the space closure group.

Armbruster et al. [25] used intraoral photographs of the different treatment modalities assigning a number between 1 and 5 for each of a series of 7 bipolar adjectives. On evaluation by general dentists, orthodontists, combined dental specialists and laypersons orthodontic space closure came out to be the most preferred modality esthetically. Same results were obtained by De marchi et al. ${ }^{[26]}$ when visual analog scale was used regarding satisfaction with esthetics of smile. Width-to-height ratio of the 6 anterior teeth and the gingival zenith of the tooth or the dental prosthesis located in the position of the lateral incisor was analyzed by Pini et al. ${ }^{[30]}$ and no differences was found between the 3 groups (orthodontic space closure, dental implants, and normal dentition) in the 2 parameters. However, the apparent contact dimension, obtained by measuring the distance from the gingival papilla crest to the point of contact, showed greater exposure of the interdental space in the implant group than in the orthodontic space closure and normal dentition groups.

Qadri et al. ${ }^{[29]}$ conducted a web based survey to evaluate the attractiveness of orthodontic space closure and prosthetic replacements and found that space closing procedures were perceived to be more attractive than space opening procedures. Schneider et al. ${ }^{[28]}$ found that orthodontists and dentists ranked implants and orthodontic space closure as equally pleasing whereas laypersons preferred orthodontic space closure.

In the study conducted by Josefsson and Lindsten ${ }^{[24]}$, crown length and gingiva color was evaluated to be better in orthodontic space closure group whereas crown color in dental implant group. Patient satisfaction was however found to be similar in both groups as reported by Rahimi et al. ${ }^{[34]}$ Table 2 summarizes the result.

\section{Discussion}

Decision for opening of space or closing by moving canine mesially in case of lateral incisor agenesis is supported by patient's oral findings. Blinding becomes unfeasible while measuring outcomes as treatment modality is identifiable by the clinicians, however it is possible when layperson is the evaluator. Esthetic principles can be quantitatively \& qualitatively analyzed by measuring width-height ratio, gingival zenith, apparent contact dimension and crown \& gingiva color with the help of dental casts, intra oral photographs or visual inspection.

According to Pini et al. ${ }^{[30,31,32]}$ the width height ratio for both space closure group \& implant group were similar. Since implant procedure normally requires orthodontic treatment before placement in order to adjust the width of the receptor area to that of a natural lateral incisor \& space closing group requires transformation of canine. Gingival zenith, the most apical point of the gingival contour is generally located distal to long axis for incisors \& canines, whereas it is coincident with lateral incisor long axis. Thus, esthetic gingival triangle for central incisors \& canines were found at same level 
whereas for lateral incisors it was below the level. Therefore, space closure promotes formation of inverted triangle which can be explained by the difference between gingival zenith of canines \& premolars, in relation to teeth replaced by them i.e. lateral incisor \& canines. These discrepancy can be reduced in space closure group prior to tooth recontouring. Evaluation of apparent contact dimension (ACD) in proximal areas of maxillary anterior teeth is an important parameter as it is responsible for formation of black triangles, periodontal health, esthetics \& phonetics. A higher value of ACD in implant group can be due to the alveolar bone in the agenesis area which is lower than that found in the normal conditions [30, 31, 32].

Adjacent gingiva can also play a role in esthetic outcomes of the different treatment modalities. Resorption of the alveolar bone below the mucosa causes discoloration of the gingiva adjacent to the Implant. Hence, compromising the esthetics of the implant. However, color of the implant supported crown was found to be optimal or satisfactory in comparison to the color of the canines substituting the lateral incisor because of the more yellow hue of the canine than the normal lateral incisor ${ }^{[32]}$. Evaluation of esthetics by general dentists, orthodontists, combined dental specialists, \& laypersons using qualitative tools such as visual analog scale, Eastman esthetic index Questionnaire, White Esthetic score can lead to vast variations as judgement of esthetics is more subjective \& hence can vary from one person to another or from one profession to another $[17,24,26,34]$. Natural dentition with no missing teeth was found to be most attractive by the professional groups such as orthodontists, who have extremely keen eyes to detect any deviation from normal esthetics. Laypersons on the other hand preferred canine substitution over other treatment modalities as mentioned by Schneider et al. ${ }^{[28]}$. Patient satisfaction is an important factor in attracting patient involvement \& improving clinical outcomes. Thus, Space closure \& reshaping of canine are more preferred than space opening followed by prosthesis ${ }^{[24}$, 29, 34]. Therefore, orthodontic space closure in subjects with congenital lateral incisor agenesis appeared to be reasonably stable \& better accepted by patients in comparison to prosthetic replacements

\section{Conclusion}

As it is well known that maxillary lateral incisor agenesis can be managed using different treatment modalities including orthodontic space closure/canine substitution, prosthetic replacements \& implant. Each modality has its pros and cons along with different applicability based on thorough examination. According to this systematic review, it can be concluded that esthetic outcomes of all these modalities was found to be satisfactory for patients as well as for the dentists, however orthodontic space closure was considered to be the most appropriate modality for lateral incisor agenesis pertaining to esthetics. Since canine replaces the missing lateral incisor in orthodontic space closure, it has a better patient satisfaction. Preservation of original color of gingiva as well as appropriate crown length is also seen in it with no adverse effect on temporomandibular joint function but it is accompanied by drawbacks which include darker color of canine as well as gingival zenith which are apparently different from lateral incisor.

\section{References}

1. Shimizu T, Maeda T. Prevalence and genetic basis of tooth agenesis. Jpn Dent Sci Rev 2009;45(1):52-8.
2. Goya HA, Tanaka S, Maeda T, Akimoto Y. An orthopantomographic study of hypodontia in permanent teeth of Japanese pediatric patients. J Oral Sci 2008;50(2):143-50.

3. Stockton DW, Das P, Goldenberg M, D'Souza RN, Patel PI. Mutation of PAX9 is associated with oligodontia. Nat Gene 2000;24(1):18-9.

4. Peres RC, Scarel-Caminaga RM, do Espírito Santo AR, Line SR. Association between PAX-9 promoter polymorphisms and hypodontia in humans. Arch Oral Biol 2005;50(10):861-71.

5. Alves-Ferreira M, Pinho T, Sousa A, Sequeiros J, Lemos $\mathrm{C}$, Alonso I. Identification of genetic risk factors for maxillary lateral incisor agenesis. $J$ Dent Res 2014;93(5):452-8.

6. Amini F, Rakhshan V, Babaei P. Prevalence and pattern of hypodontia in the permanent dentition of 3374 Iranian orthodontic patients. J Dent Res 2012;9(3):245-50.

7. Fekonja A. Hypodontia in orthodontically treated children. Eur J Orthod 2005;27(5):457-60.

8. Sisman Y, Uysal T, Gelgor IE. Hypodontia. Does the prevalence and distribution pattern differ in orthodontic patients? Eur J Dent 2007;1(3):167-73.

9. Aktan AM, Kara IM, Şener İ, Bereket C, Ay S, Çiftçi ME. Radiographic study of tooth agenesis in the Turkish population. Oral Radiol 2010;26(2):95-100.

10. Medina AC. Radiographic study of prevalence and distribution of hypodontia in a pediatric orthodontic population in Venezuela. Pediatr Dent 2012;34(2):113-6.

11. Kokich Jr VO, Kinzer GA. Managing congenitally missing lateral incisors. Part I: Canine substitution. J Esthet Restor Dent 2005;17(1):5-10.

12. Kinzer GA, Kokich Jr VO. Managing congenitally missing lateral incisors. Part II: tooth-supported restorations J Esthet Restor Dent 2005;17(2):76-84.

13. Kinzer GA, Kokich Jr VO. Managing congenitally missing lateral incisors. Part III: single-tooth implants. J Esthet Restor Dent 2005;17(4):202-10.

14. Araújo EA, Oliveira DD, Araújo MT. Diagnostic protocol in cases of congenitally missing maxillary lateral incisors. J World Fed Orthod 2006;7(4):376-88.

15. D'Amico A. Canine teeth-normal functional relation of the natural teeth of man. J South Calif Dent Assc 1968;26:239-41.

16. Nordquist GG, McNeill RW. Orthodontic vs. restorative treatment of the congenitally absent lateral incisor-long term periodontal and occlusal evaluation. J Periodontol 1975;46(3):139-43.

17. Robertsson S, Mohlin B. The congenitally missing upper lateral incisor. A retrospective study of orthodontic space closure versus restorative treatment. Eur J Orthod 2000;22:697-710.

18. Tuverson DL. Orthodontic treatment using canines in place of missing maxillary lateral incisors. Am J Orthod 1970;58(2):109-27.

19. Rosa M, Zachrisson BU. Integrating space closure and esthetic dentistry in patients with missing maxillary lateral incisors. J Clin Orthod 2007;41(9):563-73.

20. Zachrisson BU, Rosa M, Toreskog S. Congenitally missing maxillary lateral incisors: canine substitution. Am J Orthod Dentofacial Orthop 2011;139(4):434-45.

21. Andrade DC, Loureiro CA, Araújo VE, Riera R, Atallah AN. Treatment for agenesis of maxillary lateral incisors: a systematic review. Orthod Craniofac Res 2013;16(3):129-36. 
22. Papageorgiou SN, Xavier GM, Cobourne MT. Basic study design influences the results of orthodontic clinical investigations. J Clin Epidemiol 2015;68(12):1512-22.

23. Silveira GS, de Almeida NV, Pereira DM, Mattos CT, Mucha JN. Prosthetic replacement vs space closure for maxillary lateral incisor agenesis: a systematic review. Am J Orthod Dentofacial Orthop 2016;150(2):228-37.

24. Josefsson E, Lindsten R. Treatment of missing maxillary lateral incisors: a clinical and aesthetic evaluation. Eur J Orthod 2019;41(3):273-8.

25. Armbruster PC, Gardiner DM, Whitley JB, Flerra J. The congenitally missing maxillary lateral incisor. Part 1: esthetic judgment of treatment options. World J Orthod 2005;6(4):376-81

26. De-Marchi LM, Pini NI, Ramos AL, Pascotto RC. Smile attractiveness of patients treated for congenitally missing maxillary lateral incisors as rated by dentists, laypersons, and the patients themselves. J Prosthet Dent 2014;112(3):540-6.

27. Thams V, Tarjuelo I, Rico M, García-Camba P, Díaz A, Vázquez $\mathrm{S}$ et al. Agenesis of upper lateral incisors: aesthetic evaluation of the different therapeutic options. Cient Dent 2009;6(2):103-9.

28. Schneider U, Moser L, Fornasetti M, Piattella M, Siciliani G. Esthetic evaluation of implants vs canine substitution in patients with congenitally missing maxillary lateral incisors: Are there any new insights? Am J Orthod Dentofacial Orthop 2016;150(3):416-24.

29. Qadri S, Parkin NA, Benson PE. Space closing versus space opening for bilateral missing upper lateralsaesthetic judgments of laypeople: a webbased survey. J Orthod 2016;43(2):137-46.

30. Pini NI, De-Marchi LM, Gribel BF, Ramos AL, Furquim LZ, Pascotto RC. Analysis of width/height ratio and gingival zenith in patients with bilateral agenesis of maxillary lateral incisor. Dental Press J Orthod 2012;17(5):87-93.

31. Pini NP, De-marchi LM, Gribel BF, UbaldinI AL, Pascotto RC. Analysis of the golden proportion and width/height ratios of maxillary anterior dentition in patients with lateral incisor agenesis. J Esthet Restor Dent 2012(6):402-14.

32. Pini NP, De-Marchi LM, Gribel BF, Pascotto RC. Digital analysis of anterior dental esthetic parameters in patients with bilateral maxillary lateral incisor agenesis. J Esthet Restor Dent 2013(3):189-200.

33. De-Marchi LM, Pini NI, Ramos AL, Pascotto RC. Smile attractiveness of patients treated for congenitally missing maxillary lateral incisors as rated by dentists, laypersons, and the patients themselves. J Prosthet Dent. 2014;112(3):540-6.

34. Rahimi F, Moradpoor H, Raissi S, Akbari N, Golshah A. Study of esthetic outcomes of maxillary lateral incisor agenesis treatment by orthodontic space closure versus implant placement. Ann Dent 2018;6(4):402-5. 